\title{
Natural History of Persistent Ductus Arteriosus
}

\author{
MAURICE CAMPBELL
}

\author{
From Guy's Hospital, London S.E.1, and the Institute of Cardiology, London W.1
}

The natural history of typhoid fever is not too difficult to describe. It needs only accurate observers who have followed groups of patients for some months. For cardiac infarction, it is more difficult since this leaves some residual disability, a risk of recurrences, and a shorter expectation of life. Several follow-up studies for 10-20 years have, however, given us a fair picture.

It is much harder to describe the natural history of persistent ductus arteriosus or of any malformation of the heart, except those like aortic atresia that cause the early death of all subjects. The problem is more akin to that of the Government Actuary in estimating the expectation of life in the general population. Here the observer does not live long enough to follow a group of the observed through their lives, and has to work from the proportions dying each year at various ages and so on.

Everyone agrees that the expectation of life for those with persistent ductus arteriosus is shortened, but their lives are often too long to be covered by a doctor's ordinary time in practice. A reasonable, but possibly less accurate, method is dividing the patients into decades when they were under observation, studying the mortality and other events in each decade separately, and combining them to show a picture of the outlook for life. This method was used by Campbell and Baylis (1956) for coarctation, and by Campbell, Neill, and Suzman (1957) for atrial septal defect, and is used here with the much greater precision that follows from measuring the patient-years-the number of patients multiplied by the average number of years they were under observation.

There are special difficulties about the natural history of most malformations of the heart because there was such a short interval between the times when they were diagnosed with any frequency and when they began to be relieved or cured by operation. More than a century ago Wilkinson King

Received May 4, 1967. "diagnosticated patescence of the ductus" in a patient whose heart in the Guy's Museum has long been familiar to me (Babington, 1847), and Chevers wrote about it in 1845 . Gibson gave his wellknown description of the murmur in 1898, but it was a long time before there was anything more than reports of one or two cases with necropsies.

In the 1930s Perry (1931) and Muir and Brown (1932) were writing about persistent ductus arteriosus in schoolchildren. My experience of it then, and that of most physicians, was of a few young women with trivial symptoms and of one or two children dying each year with subacute bacterial endocarditis, though we knew these children were only a small proportion of the whole. There was little else till the classic paper of Maude Abbott (1936) on 1000 reported necropsies of patients with cardiac malformations.

In 1939, Gross and Hubbard reported successful ligation of a patent ductus and this stimulated an interest in its natural progress without operation. In particular, two American papers that will be discussed tried to answer this question from the ages at death of those with reported necropsies.

After the war, about 1946-47, an increasing number of cases of subacute bacterial endocarditis was being cured by penicillin, with a resultant change in the expectation of life, which is reflected in the present series. About the same time an interest in malformations of the heart and their surgical treatment was becoming widespread in many countries. There had been no adequate time for any good study of the natural history of persistent ductus arteriosus before this was made difficult by the operation, which is generally a complete cure giving a normal expectation of life.

Even so, Benn (1947) and Cosh (1957) carried out a follow-up of children with this anomaly from the school clinics of Carey Coombs and Perry at Bristol. This has been most useful in establishing something about its natural history. Recently Bruce Perry (personal communication, 1966) tried 
to continue this, but found that the large proportion who had now been operated on made it impracticable. It seems likely that such a well-planned study will not be possible in the future.

Soon the physicians who are advising operation for persistent ductus arteriosus will have no experience of its natural course without this. It seems that someone who has lived through this period of change should try to collect what he can before it is too late, especially about the numbers in whom the ductus closes spontaneously and the mortality.

\section{Spontaneous Closure of Ductus after Infancy}

Functional closure of the ductus often occurs within a few hours of birth and, anatomically, it is generally closed within six weeks (Wood, 1956). Throughout the first year, others continue to close, but about 1 per cent may still be open at the end of the first year (Brown, 1950). After this it is less likely to close and may be called persistent.

It may, however, close spontaneously at almost any age. Most of those who are interested have seen examples, e.g. Shapiro and Keys (1943); "two who have been followed for years", and Gilchrist (1945), 1 closed and 1 closing. Because no one had reported many such cases, I thought it was unusual and unimportant until a few years ago. A study of the evidence shows this is wrong.

In a discussion, Brown (1945) said he had seen 2 examples among 63 patients and gave the length of time for which they had been followed. I can say, therefore, that these 2 occurred in a group followed for about 627 patient-years, a rate of 0.32 per cent per annum. Benn (1947) found that the ductus had closed in 2 among 46 children followed for 398 patient-years, a rate of 0.5 per cent.

Brown (1950) wrote that there were now 5 closures among the 156 personal cases of Brown and Muir, the duct having closed in one of these at the age of 34, after 17 years' observation. It seems likely that these would have raised the rate of closure to 0.5 per cent, but details of the length of follow-up were not given and cannot now be obtained as the records were lost after Brown's death (D. C. Muir, 1966, personal communication). Brown (1950, p. 125) wrote "the adult case of patent ductus is a rare visitor to the clinic and the condition appears equally rare in the routine post-mortem examination. It therefore seems that . . . there must be spontaneous closure of the ductus more often than is generally realised". No one saw that adequate data for deciding how many would close were available.

Cosh (1957), including Benn's cases, found 4 closures in 61 patients and gave enough details to calculate his follow-up as 669 patient-years (since his group III of direct hospital admissions should be included for this purpose but not for the next section on mortality). This gives a closure rate of 0.6 per cent per annum.

Three examples among 168 patients and 2 others occurred soon after in my group (Campbell, 1955), but it was still not realized that with the length of follow-up a closure rate could be calculated. A man, aged 37-44, was leading a normal life and had been accepted for life assurance and for an operation without comment on his heart, but on several occasions a faint continuous murmur could be heard. A persistent ductus arteriosus had been diagnosed by Dr. Parsons-Smith when the patient was between the ages of 12 and 17, and during that time the National Heart Hospital notes at several visits recorded a loud continuous murmur and no doubt had ever been felt about the diagnosis.

A woman, aged 31-38, came to hospital only to bring her daughter with coarctation. On questioning, she said a persistent ductus arteriosus had been diagnosed when she was a schoolgirl, which proved, I think, that the faint murmur heard at several visits must have been much louder and more continuous when she was at school.

A girl was under my regular observation from the age of 3 to 7 and no doubt was felt about the diagnosis or the continuous murmur. To my surprise, when she came into hospital for operation no murmur could be heard, and the closure of her ductus was supported by her heart becoming smaller.

Two young men had had continuous murmurs since school days. In one at 20 and in the other at 22 years of age, the murmur became much fainter and was generally heard only in systole. In the former, cardiac catheterization at that time failed to prove any left-to-right shunt. I have not included two girls, aged 7 and 9, in whom I had no doubt of the diagnosis but catheterization failed to prove it, because there may have been some other cause for their murmurs.

Five closures, complete or nearly so, in 546 patient-years means an annual rate of 0.9 per cent. This is higher than in the other series shown in Table I, perhaps because cases where the ductus was nearly but not completely closed were included.

Taking the four series together, 11 examples in 1842 patient-years gives a rate of 0.6 per cent per annum. Sometimes the age when the ductus closed could be reported only as "between 10 and 23 years". Including a patient of Gilchrist, since we do not know the age of one of Brown's, 2 closed in the 1st, 3 in the 2 nd, 4 in the 3rd, and 2 in the 4th decade. The numbers are small but it looks as if the rate was fairly constant, at least for the first four decades. 
TABLE I

CLOSURE OF A PERSISTENT DUCTUS ARTERIOSUS

\begin{tabular}{l|c|c|c|c}
\hline \multicolumn{1}{|c|}{ Author } & \multicolumn{2}{|c|}{ No. of patients } & $\begin{array}{c}\text { Patient- } \\
\text { years }\end{array}$ & $\begin{array}{c}\text { Percentage } \\
\text { closing } \\
\text { per } \\
\text { annum }\end{array}$ \\
\cline { 2 - 3 } & Closing & Total & & \\
\hline Brown (1945) & $2 \star$ & 63 & 627 & 0.32 \\
Benn (1947) & $2 \dagger$ & $46 \dagger$ & $398 \dagger$ & 0.50 \\
Campbell (1955 & 5 & 168 & 546 & 0.90 \\
and later) & 4 & 61 & 669 & 0.60 \\
\hline Cosh (1957) & 11 & 292 & 1842 & 0.60 \\
\hline Total & 1 & & \\
\hline
\end{tabular}

* The 3 additional cases of Brown (1950) are not included as the period of observation is not known (see text).

+ Benn's cases were included in the figures of Cosh, so are not added in again.

Until we know how many patients die at different ages, we cannot calculate how often the ductus closes throughout life. My final calculations (see later) show that 15 per cent will have closed by 30 , when the subjects enter a more dangerous period of life, and $20 \pm 3$ per cent by the age of 60 (Table V), in addition to 2.8 per cent who had closed but died subsequently from other causes.

This finding is not given as a reason for deferring a curative operation, except in a few subjects where the flow is small and the signs suggest that the ductus is already closing.

\section{Mortality Rates in Patent Ductus}

In Infancy. The very high mortality in infancy has been known for a long time. It falls sharply and in an exponential curve from the first week to the end of the first year. The deaths in this year may amount to $30 \pm 10$ per cent (Hay, 1966; Campbell, 1968). In this paper we are discussing the progress of those who survive the first one or two years.

In Patients Aged 2-19. Wilson and Lubschez (1942) provided the earliest figures with a defined time of observation so that they can be used to cal- culate a mortality rate. This term is used to mean the percentage who die in each year. In 38 patients aged 2-19 there was only one death, though there had been 14 in the first two years. One death in 367 patient-years gives the low rate of 0.27 per cent. They reported also two non-cardiac deaths of patients aged 49 and 55, but without the numbers at risk or the time of observation.

Brown (1945) found 2 deaths in 63 patients followed for an average of 10 years. Assuming that three-quarters of these were under 20 , as both the deaths were, the 2 deaths in 470 patient-years (my calculations from his details about the length of the follow-up) gives a rate of 0.43 per cent.

Benn (1947) had no deaths in 9 years among 30 unselected schoolchildren, but 4 deaths in 8 years among 16 children referred to him from elsewhere. Since 3 of these were sent into hospital with bacterial endocarditis from which they died, it seems fairer to omit them in trying to estimate the mortality in an unselected series. The 1 death in 270 patient-years (under 20) gives a rate of 0.37 per cent.

Cosh (1957) included Benn's results in his longer inquiries so they are not added again in Table II. He now found 4 deaths (apart from the 3 excluded in Benn's series) in 61 patients followed, on the average, for more than 10 years. But nearly half his follow-up and 2 of his deaths were now of patients aged 20 or over, so will be discussed later. His 2 deaths in 348 patient-years give a higher mortality rate of 0.57 per cent.

I cannot be sure that I have distributed the patient-years for Brown or Benn or Cosh exactly rightly between the different age-groups. I have been guided by what they say about the ages and the lengths of the follow-ups, but the greatest error this can have produced is to make the rates rather too low in Table II and too high in Table III or vice versa.

These four series consisted mainly of unselected schoolchildren with persistent ductus. The 5

TABLE II

DEATHS IN SUBJECTS AGED 2-19 YEARS WITH PERSISTENT DUCTUS ARTERIOSUS

\begin{tabular}{|c|c|c|c|c|c|c|c|c|}
\hline . & $\begin{array}{c}1 \\
\text { Wilson and } \\
\text { Lubschez } \\
\text { (1942) }\end{array}$ & $\underset{\text { Brown }}{2}$ & $\begin{array}{c}3 \\
\text { Benn } \\
(1947)\end{array}$ & $\begin{array}{c}\text { Cosh } \\
\text { (1957) }\end{array}$ & $\begin{array}{c}\text { Total } \\
\text { Series } \\
1-4\end{array}$ & $\begin{array}{c}5 \\
\text { Welti and } \\
\text { Koerperich } \\
\text { (1942) }\end{array}$ & $\underset{\substack{6 \\
\text { Campbell }}}{6}$ & $\begin{array}{c}\text { Total } \\
\text { Series } \\
1-6\end{array}$ \\
\hline $\begin{array}{l}\text { No. of patients } \\
\text { No. of deaths } \\
\text { Patient-years } \\
\text { Mortality per cent per } \\
\text { annum }\end{array}$ & $\begin{array}{c}38 \\
1 \\
367 \\
0 \cdot 27\end{array}$ & $\begin{array}{c}47 \\
2 \\
470 \\
0 \cdot 43\end{array}$ & $\begin{array}{r}46 \\
1(+3 *) \\
270 \\
0.37\end{array}$ & $\begin{array}{c}\mathbf{6 1} \\
2\left(+3^{\star}\right) \\
348 \\
0.57\end{array}$ & $\begin{array}{r}146 \\
5 \\
1185 \\
0.42\end{array}$ & $\begin{array}{c}11 \\
12 \\
121 \\
0.9\end{array}$ & $\begin{array}{l}123 \\
2 \\
332 \\
0 \cdot 6\end{array}$ & $\begin{array}{c}280 \\
8 \\
1638 \\
0 \cdot 49\end{array}$ \\
\hline
\end{tabular}

* These 3 deaths have been omitted from our calculations because the patients were admitted with subacute bacterial endocarditis and died from it. Omitting the group from which these patients came, the total of patient-years for Benn and Cosh in Tables II and III combined is less than in Table $I$. 
deaths of those between 3 and 19 years of age in 1185 patient-years show a mortality rate of 0.42 (Table II). Before going on to older patients, the findings for this age-group in two hospital series of all ages will be considered.

Welti and Koerperich (1948) studied 54 patients seen in 1920-47, when 7 had died, 34 were still living, and 13 had been lost to follow-up. The 6 cardiac deaths took place at $17,21,24,29,36$, and 39 years, respectively, and the last 3 had been followed for an average of 9 years. The average time of follow-up for the living patients was probably about 11 years. Assuming this was the same for the different age-groups, the 1 death among 11 under 20 gives a rate of 0.9 per cent.

In the 123 patients of Campbell (1955) who were under 20 , the follow-up was for only $2 \cdot 7$ years, as most of them soon had an operation. The 2 deaths give a mortality rate of 0.6 per cent.

For the last two series combined it is 0.66 , which is only about 50 per cent above the series that were made up mainly of unselected schoolchildren. This confirms the view of most physicians that the shortterm outlook for children with persistent ductus is good since the treatment of subacute bacterial endocarditis with antibiotics was introduced.

The mortality rate for the 6 series combined is 0.49 per cent per annum (8 deaths in 1638 patientyears). The figure 0.5 has been used for subsequent calculations.

In Patients Aged 20-29. Some of the unselected schoolchildren were followed for many years and are carried on into this and the following age-group (see Table III). The total figures are perhaps less reliable because they depend mainly on two series seen at hospital, those of Welti and Koerperich (1948) and of Campbell (1955).

The former show a mortality rate of 2.7 for the 10 patients, and the latter a rate of $3 \cdot 1$ for the 20 patients of this age. The final rate when all the available figures are combined is much lower than in these two series, 1.0 per cent; but it is still double the rate during the first two decades.

In Patients Aged 30 or more. From Cosh's series there are 2 deaths of subjects followed up to this age-group, and Welti and Koerperich have 2 deaths among their 13 patients. Campbell (1955) has 4 deaths among his 25 patients of this age: they had been followed for an average of 6 years, longer than the others because of reluctance to advise operation for older patients who were doing badly until it was gradually learnt how much they too could benefit.

Combining the results shown in Table III, the mortality rate for this age-group is 1.8 per cent,
TABLE III

MORTALITY IN PATIENTS OVER 20 WITH PERSISTENT DUCTUS ARTERIOSUS

\begin{tabular}{|c|c|c|c|c|}
\hline \multirow[t]{2}{*}{ Authors } & \multicolumn{2}{|c|}{ Aged 20-29 } & \multicolumn{2}{|c|}{ Aged 30 and over } \\
\hline & $\begin{array}{l}\text { No. of } \\
\text { deaths in } \\
\text { patient- } \\
\text { years }\end{array}$ & $\begin{array}{l}\text { Mortality } \\
\text { rate per } \\
\text { annum }\end{array}$ & $\begin{array}{l}\text { No. of } \\
\text { deaths in } \\
\text { patient- } \\
\text { years }\end{array}$ & $\begin{array}{l}\text { Mortality } \\
\text { rate per } \\
\text { annum }\end{array}$ \\
\hline $\begin{array}{l}\text { Wilson and } \\
\text { Lubschez (1942) }\end{array}$ & 0 in 70 & 0 & - & - \\
\hline $\begin{array}{l}\text { Brown (1945) } \\
\text { Cosh (1957) } \\
\text { Welti and Koer- } \\
\text { perich (1948) }\end{array}$ & $\begin{array}{l}0 \text { in } 105 \\
0 \text { in } 154 \\
3 \text { in } 110\end{array}$ & $\begin{array}{l}0 \\
0 \\
2 \cdot 7\end{array}$ & $\begin{array}{l}0 \text { in } 52 \\
2 \text { in } 95 \\
2 \text { in } 143\end{array}$ & $\begin{array}{l}0 \\
2 \cdot 2 \\
1 \cdot 4\end{array}$ \\
\hline Campbell (1955) & 2 in 65 & $3 \cdot 1$ & 4 in 149 & $2 \cdot 7$ \\
\hline Total & 5 in 504 & $1 \cdot 0$ & 8 in 439 & $1 \cdot 8$ \\
\hline
\end{tabular}

nearly four times as high as the rate in the first two decades. Admittedly it is based partly on patients attending hospital who at this age do not often come unless they have symptoms. But in the next section I shall show how many more were likely to die within 5 or 10 years and were saved from this only by having the ductus divided or ligated.

The mortality rates shown here may, therefore, be higher than in the general population because of the unknown number of subjects with persistent ductus arteriosus who do not come to hospital; but they are certainly lower than for the true natural history because of the many lives saved by operation. I have little doubt that the latter mechanism offsets the former possible error and that the mortality rate shown in Table III is too low.

\section{Effect of Operations in Older Patients}

Serious deterioration in many of our older patients was arrested or reversed by operation. This must have made the observed mortality much lower than it would have been naturally. This section is based on 45 patients aged 20 years or more, all but 3 of whom were reported by Campbell (1955).

They have been divided into groups A-D according to the size of the heart, the cardiographic signs of left ventricular strain, their ability to lead a normal life or otherwise, and their deterioration or stability.

Group A: Patients doing well without any special signs but often with some enlargement of the heart, including some where the ductus was closing. These are likely to do well for a very long time.

Group B: Those apparently well but with a large heart or signs of left ventricular strain. Several showed no change for 2-6 years, but three who died had been in this group from 6 to 8 years before. 
TABLE IV

CONDITION OF 45 PATIENTS OVER 20 (CAMPBELL, 1955)

\begin{tabular}{|c|c|c|c|c|c|}
\hline Age-group & No. of cases & $\underset{\text { well }}{\text { Group }}$ A: doing & $\begin{array}{l}\text { Group B: seeming } \\
\text { well but some signs }\end{array}$ & $\begin{array}{l}\text { Group C: worse and } \\
\text { more severe signs }\end{array}$ & $\begin{array}{l}\text { Group D: those who } \\
\text { have died }\end{array}$ \\
\hline $\begin{array}{l}20-24 \\
25-29 \\
30-39 \\
40 \text { and over }\end{array}$ & $\begin{array}{r}11 \\
9 \\
17 \\
8\end{array}$ & $\begin{array}{l}9(6) \dagger \\
3(2) \\
3 \\
1\end{array}$ & $\begin{array}{l}0 \\
3(2) \\
3(1) \\
1\end{array}$ & $\begin{array}{l}1 \\
2(2) \\
8(7) \\
5(3)\end{array}$ & $\begin{array}{l}1 \\
1 \\
3 \\
1\end{array}$ \\
\hline
\end{tabular}

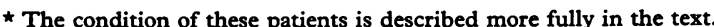

+ The figures in brackets are the patients who had the ductus closed by operation.

Group C: Those finding it difficult to work or having very large hearts (cardiothoracic ratio $65 \%$ ) or severe left ventricular strain, often both. Many of these would not, I think, have lived more than 5 or, at the most, 10 years.

\section{Group D: Those who have died.}

They were divided also into 5-year age-groups; but where there did not seem much difference they have been combined as shown in Table IV. The smaller numbers in brackets show the numbers who had operations.

Most of the patients in groups A and B were advised to have operations as a routine and would have lived for many years with or without this. It was very different with the group $C$ patients. Many of them would, I think, have died within 5 years and nearly all in 10-15 years. This would have increased enormously the mortality rates shown in Table III, probably from 1.0 to 1.5 per cent in the 20-29 group, from 1.8 to at least 2.5 in the $30-39$ group, and to 4.0 per cent in those aged 40 and over.

Admittedly, most of these patients came to hospital because of their symptoms. Some have argued that there are many at home without symptoms, but I doubt this. In three hospital series (see Table VIII) only 9, 6, 2, and 1 per cent were in the 4th, 5th, 6th, and 7th decades, respectively. The steady fall in these numbers suggests that those attending hospital in the 4th decade are about half of all at that age with persistent ductus arteriosus.

Even in the unselected series of Cosh (1957) 16 subjects had been operated on (in addition to the 12 omitted because they were referred for this). They would not be the 16 with the fewest signs and symptoms and one, aged 24, had atrial fibrillation and heart failure.

I know no other figures to make mine more certain but have much general support. Fairley and Goodwin (1959) give a similar impression of their 43 patients aged 20 or more. Nearly four-fifths had left ventricular hypertrophy, three-fifths had large hearts, and the same number had dyspnoea: only a quarter were without symptoms. Gilchrist (1945) had 6 patients over 20, of whom 1 died, 2 showed serious and 1 slight deterioration, and only 2 were doing well. Gross (1952) with his wide experience of 525 operations thought that most patients from the 3rd decade onwards had increasing symptoms and difficulty in carrying on their work, while most children were leading a normal life.

It is not surprising that the left ventricle so often fails in the 4th and 5th decades when it has been pumping out twice the normal volume of blood for 30 or 40 years. The volume shunted through the ductus averaged 6.2 litres and the systemic flow 5.0 litres in all the patients with a persistent ductus who had been catheterized at Guy's Hospital (Campbell, 1956). The left atrium and ventricle have to deal with this, and it must double their work and tend to increase their volume. Sometimes there is also the added work for the right ventricle, with a rising pulmonary arterial pressure.

\section{EXPeCtation OF LIFE FOR ThOSE WITH Persistent DUCtUS ARTERIosus}

We are now in a position to calculate the mortality and the number in whom the duct has closed. There is reasonable evidence that the ductus closes in 0.6 per cent per annum, certainly for the first four decades, and we have assumed half this rate thereafter. There is evidence that 0.5 per cent die each year in the first two decades; 1.0 or, as I think more likely, 1.5 in the $3 \mathrm{rd}$ decade; 2.0 or more likely 2.5 in the 4 th; and 4.0 per cent each year in later decades.

Starting with 1000 subjects who survived their first year and with only 9 years of the first decade, the results are shown in Table V. The first line shows the expected number of deaths in $\mathbf{1 0 0 0}$ of the general population. They are calculated from the English Life Table, No. 11 (1957) for an imaginary population where women are twice as common as men. The second line shows the expected number of deaths among 1000 subjects with persistent ductus. They have been calculated for each year though only those at the end of each decade are shown. Those 
TABLE V

CALCULATED EXPECTED DEATHS AND SURVIVORS FROM 1000 PATIENTS WITH PERSISTENT DUCTUS ARTERIOSUS ALIVE AT 1 YEAR

\begin{tabular}{l|c|c|c|c|c|c|c|}
\hline & \multicolumn{2}{|c|}{ Ages (yr.) } & At 40 & At 50 \\
\hline $\begin{array}{l}1000 \text { Normal Subjects } \\
\text { Dead }\end{array}$ & At 10 & At 20 & & & \\
\hline
\end{tabular}

1000 Patients with Persistent Ductus Arteriosus Alive at 1 Year

\begin{tabular}{|c|c|c|c|c|c|c|}
\hline $\begin{array}{l}\text { Dead } \\
\text { Living with duct open }\end{array}$ & $\begin{array}{r}44 \\
902\end{array}$ & $\begin{array}{r}88 \\
804\end{array}$ & $\begin{array}{l}202 \\
(678) 643\end{array}$ & $\begin{array}{l}\text { (293) } 336 \\
\text { (512) } 471\end{array}$ & $\begin{array}{l}(471) 500 \\
(324) 298\end{array}$ & $\begin{array}{l}587) 609 \\
(210) 191\end{array}$ \\
\hline With duct closed & 54 & 108 & 155 & (195) 193 & (205) 202 & (203) 200 \\
\hline
\end{tabular}

The figures inside the blocked-off area are less certain than the others.

See text for the significance of the figures in parentheses.

calculated from the lower mortality rates in the third and 4 th decades ( 1 and $2 \%$ ) are shown in brackets and those from the higher, and more likely, mortality rates $(1.5$ and $2.5 \%)$ without brackets. The mortality after 30 rests on less firm evidence because it depends on deductions about the number of adult patients who would have died had they not been cured by operation. It is, therefore, shown in the blocked-off area.

The third line shows the number still living with a persistent ductus at the end of each decade. The fourth line shows the number among 1000 subjects with this anomaly where it has closed spontaneously. These smaller figures have been calculated for the end of each decade. These subjects are now saved from the special risks of death (for those with a persistent ductus) and have only the normal risk. The very small number who can be expected to die has been added to the deaths in the second line. Only after 40 is the number large enough to make a real difference, and after 50 it is a trifle larger than the number of new closed ducts.

These calculations suggest that 34 per cent of the subjects with persistent ductus have died by 40 , instead of 4 per cent among normal subjects, and in 19 per cent the ductus has closed. By 60 , it has closed in $20 \pm 3$ per cent, another $19 \pm 7$ per cent are living, but $61 \pm 10$ per cent have died. The ranges given show the rough limits of many calculations made with different assumptions that seemed possible but less likely than those finally adopted.

Even this fairly high mortality is less than I would have expected in the three later decades, and suggests it was right to use the higher mortality rate for the 3rd decade onwards. The higher and lower rates make more difference at 40 than at 60 because the lower rate leaves a larger population over 40 exposed to the highest mortality rate.

The cumulative deaths of those with persistent ductus arteriosus are between 5 and 8 times as many as those expected in the general population, until after 50 when the ratio falls. The mean age at death, assuming that deaths between 20 and 29 average at 25 and so on, is 35 years. If those still living are included, it is increased to 41 or 42 years according to whether they live to a mean of 65 or 70 years. These figures apply to a period of change when there were still deaths from subacute bacterial endocarditis but in decreasing numbers. They will now be compared with series based on reported necropsies.

\section{Ages of Patients with Reported Necropsies}

This was the first method used to decide the natural expectation of life for those with persistent ductus. If these necropsies are a representative sample of those at risk, the answer should be correct (see p. 10). Three series of 1936-43 will be considered.

Maude Abbott (1936) found the mean age at death in the 92 necropsies of those with this defect was 24 years. But 20 of them died in infancy, so for the other 72 it was raised to 30 years.

Bullock, Jones, and Dolley (1939) reported on 80 necropsies of patients over 3 and on the causes of death. They expressed their conclusions as the numbers who had died at 14, 30, and 40 years, which are not easy to compare with other results. But from their valuable Figure showing all the ages of death, I have read off the numbers dying from all causes, including 11 that were non-cardiac or uncertain. These are shown as percentages in each decade in Table VI and the mean age at death was just under 29 years.

Keys and Shapiro (1943) discussed 60 necropsies, including 4 of their own, in patients who had died at 17 or older. They found the average age at death was 35.5 for the women and 39 years for the men, 
TABLE VI

PERCENTAGE OF DEATHS IN EACH DECADE

\begin{tabular}{|c|c|c|c|c|c|c|c|}
\hline Source & $3-9$ & $10-19$ & $20-29$ & $30-39$ & $40-49$ & $50-59$ & $60-69$ \\
\hline $\begin{array}{l}\text { Reported necropsies (Bullock et al., 1939) } \\
\text { Reported necropsies (Keys and Shapiro, 1943) } \\
\text { Average* } \\
\text { Deaths in series used in Tables II and III † }\end{array}$ & $\begin{array}{c}5 \\
(10) \\
7 \cdot 5 \\
8\end{array}$ & $\begin{array}{l}24 \\
(17) \\
20 \cdot 5 \\
24\end{array}$ & $\begin{array}{l}22 \\
25 \\
23 \cdot 5 \\
24\end{array}$ & $\begin{array}{l}28 \\
18 \\
23 \\
28\end{array}$ & $\begin{array}{l}9 \\
16 \\
12 \cdot 5 \\
12\end{array}$ & $\begin{array}{c}9 \\
10 \\
9 \cdot 5 \\
4\end{array}$ & $\begin{array}{l}3 \\
4 \\
3 \cdot 5 \\
0\end{array}$ \\
\hline
\end{tabular}

* These are based on reported necropsies. The mean age at death was 30.6 years.

t These are based on subjects from the series of 1942-57 used in calculating the mortality rates. The mean age at death was 27.5 years, but most are still alive.

which gives a combined mean of 36.5 , instead of the 62.7 years that was expected from the life tables of that time. Even those who had reached 17 had less than half the future expectation of life.

From the ages of their cases given in their appendix, I have placed 58 of them in decades and added 19 hypothetical younger cases to make the same percentage under 17 years as in the series of Bullock et al. The results are shown as percentages in the second line of Table VI. Clearly the exclusion of those who died before 17 artificially increases the mean age at death. Adding the younger patients, as just described, reduces it from 36.5 to 32 years, which is only a little older than the 30 years of Abbott and the 29 years of Bullock et al.

Though Bullock et al. had more deaths in the 4th, and Keys and Shapiro more in the 5th decade, there is reasonable agreement between them. In the average of the two series, the $2 \mathrm{nd}$, 3rd, and 4th decades each have between 20 and 24 per cent of the deaths (Table VI).

Many have thought, e.g. Wood (1956), that this method gives too gloomy a view of the prognosis and that an undue number of younger patients were reported. No doubt old men who die at home with a cerebral thrombosis have fewer necropsies than some other groups; but I cannot see why a patient who had or still has an interesting murmur and dies is not equally likely to have a necropsy at any age between 20 and 50 or even 60 . Those who die with a balanced shunt and no murmur may be diagnosed as heart failure only, but most of these are in the 4th or 5th decades so would have to be very numerous to make much change in the mean age of death.

\section{Comparison of Mortalities as Calculated and AS Found AT NECROPSIES}

The series of 1942-57 that have been used to calculate the mortality rates of 10-25 years ago are less open to the possibility of bias in selection. Most had been followed from some years before they died and several since they were unselected schoolchildren. The 21 deaths of Tables II and III and 4 others mentioned in these series are shown in the last line of Table VI, and agree well with the ages of the reported necropsies up to 50 , and the deaths of those who still enjoy good health will ultimately increase the numbers dying after 50 years.

The large differences between the cumulative mortalities as calculated and as found in the reported necropsies (Tables VII) are partly accounted for by the number in whom the ductus closes spontaneously. This was not recognized at the earlier period. It accounts for about half the difference in the 2nd-6th decades and for all in the 1st decade.

Much of the remaining difference is due to the lives now saved by the cure of subacute bacterial endocarditis. In the series of 1942-57 used for the calculations, 33 per cent of the deaths were still due to subacute bacterial endocarditis, but in the earlier series of 1936-43, 45 per cent were due to this cause (see later). If the deaths from this in the former series are increased by two-thirds it will raise their proportion to the same 45 per cent. This in effect

TABLE VII

COMPARISON OF CUMULATIVE MORTALITIES FROM CALCULATIONS IN TABLE V AND FROM REPORTED NECROPSIES

\begin{tabular}{|c|c|c|c|c|c|c|c|}
\hline & \multicolumn{6}{|c|}{ Percentage of subjects dying before } & \multirow{2}{*}{$\underset{60(\%)}{\text { Living at }}$} \\
\hline & $10 \mathrm{yr}$. & $20 \mathrm{yr}$. & $30 \mathrm{yr}$. & $40 \mathrm{yr}$. & $50 \mathrm{yr}$. & $60 \mathrm{yr}$. & \\
\hline $\begin{array}{l}\text { As calculated in Table V } \\
\text { Special calculation: see text } \\
\text { Reported necropsies (Table VI) }\end{array}$ & $\begin{array}{c}4 \cdot 4 \\
(5 \cdot 3) \\
7 \cdot 5\end{array}$ & $\begin{array}{c}9 \\
(11) \\
28\end{array}$ & $\begin{array}{l}20 \\
(24) \\
51 \cdot 5\end{array}$ & $\begin{array}{l}34 \\
(41) \\
74 \cdot 5\end{array}$ & $\begin{array}{l}50 \\
(60) \\
87\end{array}$ & $\begin{array}{l}61^{\star} \\
(73) \\
96 \cdot 5\end{array}$ & $\frac{19 \star}{3 \cdot 5}$ \\
\hline
\end{tabular}

* The other 20 per cent are the patients in whom the ductus has closed. They account for half the difference between the calculated mortality and that found at reported necropsies in most decades (see text). 
TABLE VIII

AGES OF PATIENTS WITH PERSISTENT DUCTUS ARTERIOSUS IN MEDICAL CLINICS

\begin{tabular}{l|c|c|c|c|c|c|c|c}
\hline \multirow{2}{*}{ Author } & \multirow{2}{*}{ No. of cases } & \multicolumn{8}{|c}{ Percentages at each age } \\
\cline { 2 - 9 } & & $0-9$ & $10-19$ & $20-29$ & $30-39$ & $40-49$ & $50-59$ & 60 and over \\
\hline Gilchrist (1945) & 82 & 40 & 29 & 12 & 9 & 6 & 4 & 0 \\
Campbell (1955) & 168 & 48 & 27 & 11 & 7 & 5 & 1 & 1 \\
Wood (1956) & 115 & 36 & 32 & 15 & 9.5 & 6.5 & 1 & 0 \\
\hline Average & 365 & 41 & 29 & 13 & 8.5 & 6 & 2 & 0.5 \\
\hline
\end{tabular}

multiplies the total mortality by $1 \cdot 22$, and the figures so obtained are shown in brackets in the middle line of Table VII. Then, the closed ducts account for all the difference between the calculated and observed figures at 10 and at 50 and 60 years and for more than half of the differences at 20,30 , and 40 years. I conclude that the reported necropsies of 25-30 years ago are not very far from the true picture of that time, except for the closed ducts: either they are rather too pessimistic for from 20-40 years or my calculations are too optimistic for this time.

\section{Ages of Living Patients}

These ages in the series of three physicians (Table VIII) are clearly overweighted with the fit children referred for operation. They agree closely with each other and show a mean age of only 16.7 years, but most of the children seemed likely to get on well for many years. Even in the more adult series of Welti and Koerperich, the mean age of the 34 patients who were living and mostly in good health was only 29 , already a year more than that of the 7 who had died.

The 30 per cent of patients over 20 in Table VIII have a mean age of 34 years and seem more representative of the general population with persistent ductus. If there were, in fact, many more living at 30 , there could hardly be so few seeking advice about their hearts at older ages.

\section{BACTERIAL ENDOCARDITIS AND ITS INCIDENCE}

This paper is concerned with the total deaths rather than the different varieties, but bacterial endocarditis should be discussed briefly because its successful treatment with antibiotics has brought about changes in the period under review.

Abbott (1936), Bullock et al. (1939), and Keys and Shapiro (1943) all agreed that subacute bacterial endocarditis was the most common cause of death (average $45 \%$ ), followed by heart failure (30\%). The remaining quarter was made up of other cardiovascular causes $(7 \%)$ and non-cardiac and uncertain causes $(18 \%)$. These series belong to the time when practically every case of subacute bacterial endo- carditis proved fatal. The much smaller number of deaths on which the expectation of life has been calculated still shows one-third were from this, onethird from heart failure, and one-third from other causes.

More recent series would show a further, and probably large, reduction in deaths from bacterial endocarditis. But the patients cured of this, unlike those where the ductus closes, are still exposed to further attacks and to the risk of heart failure. This last increases so sharply with age that the number living at 60 may not be greatly increased.

Cosh (1957) writes that 6 of his patients had subacute bacterial endocarditis, an incidence of 0.4 per cent per annum. He used the number of years they had lived (1451), but this neglects those of their contemporaries who were excluded because they had died with endocarditis before coming under observation. It is, I think, fairer to say that 3 cases developed in 669 patient-years, a similar incidence of 0.45 per cent per annum. Before the introduction of antibiotics this would have meant a high death rate of 4.5 per cent per decade. It is probably the main reason for the larger number of deaths observed in the earlier decades among those with reported necropsies. The 45 per cent of deaths from bacterial endocarditis in the three necropsy series suggests an incidence of 1.5 per cent per annum, taking 30 years as the average length of life. They are almost certainly too high in these series, since such patients tend to die in hospital. The true incidence, therefore, may well be over 0.45 and somewhere below 1.0 per cent per annum.

\section{SEX INCIDENCE}

There is unusual unanimity about the higher incidence in girls than in boys, and this must be referred to as an aspect of the natural history that is not understood. Every author mentioned in this paper agrees with this differential incidence, and the total figures for their combined series are 413 male, and 946 female subjects, a ratio of about 4 to 9 or more exactly 1 to $2 \cdot 29$. Campbell and Polani (1961) have suggested a possible explanation for this higher incidence in girls, but it is purely speculative. 


\section{SUMMARY AND CONCLUSIONS}

As the years pass, more physicians will be advising operation for a persistent ductus arteriosus with no personal experience of its natural course without operation. It seems important that someone who has seen this period of change should record as much as possible before it is too late. The rate of mortality and the likelihood of other changes in persistent ductus arteriosus can be expressed correctly only when the numbers at risk and the years for which they were under observation are both known.

From 4 series where these data are available we have calculated that the ductus closes spontaneously in 0.6 per cent per annum. Probably the rate is fairly constant, at least for the first four decades. This does not sound very much, but means that $20 \pm 3$ per cent will have closed by the age of 60 . This is our most important conclusion, but it does not mean that an operation which gives a normal expectation of life should be deferred, unless there is already evidence that the duct is closing.

From the same 4 series and 2 others the percentage who die each year can be calculated. The rate should be nearly correct for the first two decades, but after this, assumptions have had to be made about how many others would have died if their lives had not been saved by operations.

After the heavy mortality of infancy, mainly in the first year, most children are without symptoms and for two decades have less risk of dying $(0.5 \%$ per annum) than of the ductus closing. A few (perhaps 3 or $4 \%$ ) keep a high pulmonary arterial pressure or develop this again within a few years.

About the time the first decade changes to the second, the risk of bacterial endocarditis increases to at least 0.45 per cent per annum, and this continues for $\mathbf{4 0}$ years or more. The cure of this is not comparable with spontaneous or operative closure of the ductus, because there are still the risks of recurrent attacks of endocarditis and of heart failure, the latter risk increasing greatly with age.

From the start of the third decade, or occasionally earlier, increasing numbers of those with the larger shunts have more dyspnoea, a larger heart, and often a rising pulmonary arterial pressure. These changes lead to an increasing death rate from heart failure which may be brought on in several ways. By the age of 30 , our calculations show that about one-fifth of the subjects will have died.

From the fourth decade onwards these changes are progressively severe, with a mortality rate rising from 2.5 to 4.0 per cent per annum. By 45 , about 42 per cent will have died, but the duct will have closed in nearly a fifth. By 60 , over $60 \pm 10$ per cent will have died and the duct will have closed in $20 \pm 3$ per cent.

These calculated figures and the age of death at necropsies reported 25 or more years ago are in reasonable agreement, when allowance has been made for the number of ducts that close spontaneously and for the reduced death rate from bacterial endocarditis.

I am grateful to Dr. Deuchar for some helpful suggestions and to Drs. Bruce Perry, Benn, and Cosh for the long follow-up of Bristol schoolchildren with persistent ductus arteriosis that has proved so useful.

I should like to thank Mr. J. D. Hooker, F.I.A., Actuary to the Commercial Union Group, for the English Life Table and for valuable suggestions, especially about my Table V.

\section{REFERENCES}

Abbott, Maude (1936). Atlas of Congenital Heart Disease. American Heart Association, New York.

Babington, B. G. (1847). Cyanosis dependant on patent ductus arteriosus. Trans. path. Soc. Lond., 1, 55.

Benn, J. (1947). The prognosis of patent ductus arteriosus. Brit. Heart f., 9, 283.

Brown, J. W. (1945). Discussion on patent ductus arteriosus and its surgical treatment. In Proceedings of the Cardiac Society of Great Britain and Ireland. Brit. Heart 7., 7, 212.

- (1950). Congenital Heart Disease, 2nd ed. Staples Press, London.

Bullock, L. T., Jones, J. C., and Dolley, F. S. (1939). The diagnosis and the effects of ligation of the patent ductus arteriosus. F. Pediat., 15, 786.

Campbell, M. (1955). Patent ductus arteriosus: some notes on prognosis and on pulmonary hypertension. Brit. Heart $\mathcal{f} ., 17,511$.

- (1956). Acyanotic congenital heart disease: the Carbutt memorial lecture, 1955. Guy's Hosp. Gaz., 70, 246.

- (1968). Incidence of malformations of the heart. In A Textbook of Paediatric Cardiology, ed. Hamish Watson. Lloyd-Luke, London.

-, and Baylis, J. H. (1956). The course and prognosis of coarctation of the aorta. Brit. Heart F., 18, 475 .

- Neill, Catherine, and Suzman, S. (1957). The prognosis of atrial septal defect. Brit. med. F., 1, 1375.

-, and Polani, P. E. (1961). The aetiology of coarctation of the aorta. Lancet, 1, 463.

Chevers, N. (1845). Observations on the permanence of the ductus arteriosus, and constriction of the thoracic aorta. Lond. med. Gaz., 36 (n.s. 1), 187.

Cosh, J. A. (1957). Patent ductus arteriosus: a follow-up study of 73 cases. Brit. Heart f., 19, 13.

English Life Table, No. 11 (1957). Based on Population of England and Wales in 1951 and Deaths in 1950-52. Registrar General's Decennial Supplement, 1951.

Fairley, G. H., and Goodwin, J. F. (1959). Patent ductus arteriosus in adult life. Brit. F. Dis. Chest, 53, 263.

Gibson, G. A. (1898). Diseases of the Heart and Aorta, p. 161. Pentland, Edinburgh

Gilchrist, A. R. (1945). Patent ductus arteriosus and its surgical treatment. Brit. Heart f., 7, 1.

Gross, R. E. (1952). The patent ductus arteriosus: observations on diagnosis and therapy in 525 surgically treated cases. Amer. F. Med., 12, 472.

- , and Hubbard, J. P. (1939). Surgical ligation of a patent ductus arteriosus. Report of first successful case. F. Amer. med. Ass., 112, 729. 
Hay, J. D. (1966). Population and clinic studies of congenital heart disease in Liverpool. Brit. med. F., 2, 661.

Keys, A., and Shapiro, M. J. (1943). Patency of the ductus arteriosus in adults. Amer. Heart f., 25, 158.

Muir, D. C., and Brown, J. W. (1932). Patent ductus arteriosus. Arch. Dis. Childh., 7, 291.

Perry, C. B. (1931). Congenital heart disease as seen in elementary school children. Bristol med.-chir. f., 48, 41.

Shapiro, M. J., and Keys, A. (1943). The prognosis of untreated patent ductus arteriosus and the results of surgical intervention. Amer. F. med. Sci., 206, 174.
Welti, J. J., and Koerperich, G. (1948). Remarques sur le pronostic de la persistance simple du canal artériel à propos de 54 cas non opérés. Arch. Mal. Caur, 41, 428.

Wilson, May G., and Lubschez, Rose (1942). Prognosis for children with congenital anomalies of the heart and central vessels. Life expectancy in patent ductus arteriosus. F. Pediat., 21, 23.

Wood, P. (1956). Diseases of the Heart and Circulation, 2nd ed. Eyre and Spottiswoode, London. 